\title{
OCENA EFEKTYWNOŚCI FUNDUSZY TOWAROWYCH NA PRZYKŁADZIE FUNDUSZY METALI SZLACHETNYCH
}

\begin{abstract}
Streszczenie
Celem artykułu jest próba oceny atrakcyjności towarowych funduszy ETF. Towarowe fundusze ETF są nowym instrumentem finansowym na rynku kapitałowym. Debiut funduszy towarowych na rynku amerykańskim miał miejsce w listopadzie 2004 r., kiedy działalność zainaugurował SPDR Gold Shares (GLD), który stara się duplikować zmiany cen złota. Podstawowe zalety ETF to: wysoka płynność, prostota i przejrzystość instrumentu oraz niskie koszty zarządzania. Towarowe fundusze ETF mogą stanowić atrakcyjne narzędzie, za którego pomocą inwestorzy indywidualni mogą włączyć ekspozycję na rynki towarowe do swoich portfeli inwestycyjnych. W artykule ograniczono się jedynie do analizy największej grupy towarowych funduszy ETF - funduszy metali szlachetnych. Badania przeprowadzono w okresie 2009 - I półrocze 2015.
\end{abstract}

Słowa kluczowe: towarowe fundusze ETF, metale szlachetne, błąd odwzorowania, fundusze zarządzane pasywnie

* Adres e-mail: ugieraltowska@gmail.com. 


\section{Wprowadzenie}

Wymiana handlowa stanowi podwaliny współczesnego świata i ekonomii. Od niepamiętnych czasów handlowano dobrami naturalnymi, ponieważ zasoby w wielu miejscach (miastach, państwach) były wyraźnie zróżnicowane. W epoce kapitalizmu, gdy powszechny stał się proces akumulowania majątku, chętnie zawierano transakcje na surowcach w celu zarabiania na różnicach cenowych. Taki model inwestowania stał się popularny na przełomie XIX i XX wieku, gdy zaczęto organizować coraz lepsze centra obrotu surowcami. W latach 70. dostrzeżono, że surowce w warunkach inflacji stanowią świetną ochronę przed tym zjawiskiem. Wraz z rozwojem finansów inwestorzy zaczęli poszukiwać nowych aktywów, które charakteryzowałyby się niską korelacją względem instrumentów klasycznych celem poprawy jakości budowanych portfeli inwestycyjnych. Dodatkowym atutem takich inwestycji była wysoka płynność na rynkach towarów, wysokie historyczne stopy zwrotu oraz antycykliczny charakter zmian cen na rynkach wielu typów towarów.

Zróżnicowanie rynku towarowego jest dużo większe, niż mogłoby się pierwotnie wydawać. Znajdziemy tu m.in.:

- surowce energetyczne (głównie ropa naftowa, gaz ziemny, węgiel, ruda uranu),

- metale przemysłowe (głównie miedź, cynk, cyna, kobalt, ołów, ruda żelaza, nikiel, aluminium),

- metale szlachetne (złoto, srebro, platyna, pallad),

- żywność w postaci płodów rolnych (np. pszenica, soja, kukurydza, rzepak, kakao, cukier, kawa, bawełna, sok pomarańczowy, ryż, półtusze).

Dzięki potencjalnie wysokiej historycznej stopie zwrotu w ostatnich latach surowce cieszyły się dość dużym zainteresowaniem wśród inwestorów finansowych, należy jednak pamiętać, że rynek surowców charakteryzuje się dużą zmiennością i nieprzewidywalnością. Ceny surowców zależą przede wszystkim od wielkości popytu, który jest uzależniony od stopnia rozwoju ekonomiczno-demograficznego. W ostatnich latach bardzo duża część popytu pochodziła ze strony silnie rozwijających się gospodarek azjatyckich (głównie chińskiej i indyjskiej). Ceny są również pochodną panującej koniunktury gospodarczej (dynamika PKB), polityki banku centralnego czy finansów publicznych. Rosnący popyt nie może być natychmiast zrekompensowany analogicznym wzrostem podaży, ponieważ zwiększenie mocy wydobywczych, znalezienie nowych złóż, budowa nowych kopalń czy hut lub zmiany 
technologiczne są dhugoterminowe i kosztowne. Zwiększenie mocy wydobywczych w długim horyzoncie czasu powoduje konieczność sięgania do mniej dostępnych złóż bądź wykorzystywania bardziej zaawansowanych technologii, co z punktu widzenia ekonomii jest opłacalne tylko przy wyższej cenie surowca.

Oprócz kwestii popytowo-podażowych istotnymi czynnikami kształtującymi ceny surowców są: sytuacja geopolityczna (a w szczególności konflikty zbrojne, np. w krajach afrykańskich), warunki pogodowe, informacje o odkryciach nowych złóż, sytuacja na rynku walutowym, struktura dostaw, a przede wszystkim rozwój rynku kapitałowego.

Celem artykułu jest prezentacja towarowych funduszy ETF (exchange-traded fund) oraz ocena ich atrakcyjności jako przedmiotu inwestycji. W artykule ograniczono się jedynie do największej grupy towarowych funduszy ETF - funduszy metali szlachetnych. W 2014 r. obroty funduszami ETF opartymi bezpośrednio lub pośrednio na złocie sięgnęły $253186,7 \mathrm{mln} \$$, podczas gdy obroty wszystkimi towarowymi funduszami ETF wynosiły $505441,5 \mathrm{mln} \$$ (Lan et al. 2015). Rozpatrując wszystkie metale szlachetne (złoto, srebro, platyna, pallad) - ich udział w łącznych obrotach przekroczył $60 \%$ (we wcześniejszych latach udział był wyższy i znacznie przekraczał $70 \%$ ).

\section{Krótka historia $\mathrm{i}$ istota exchange-traded fund}

Exchange-traded fund to instrument, który łączy w sobie najlepsze cechy akcji i funduszy inwestycyjnych. Jest to rodzaj otwartego funduszu inwestycyjnego, którego celem jest śledzenie ruchu indeksów giełdowych, surowców czy koszyka innych aktywów, np. akcji lub obligacji, są to zatem fundusze zarządzane pasywnie (co zasadniczo odróżnia je od klasycznych funduszy inwestycyjnych) ${ }^{1}$. Jest to sprawdzony i akceptowany przez inwestorów instrument finansowy, który z jednej strony umożliwia stosowanie prostych strategii inwestycyjnych (prosty sposób na dywersyfikację portfela inwestycyjnego), a z drugiej - jest tańszy i bardziej zyskowny w porównaniu z klasycznymi funduszami akcji.

1 W 2008 r. SEC dopuścił do obrotu fundusze ETF zarządzane aktywnie (actively managed), których celem jest takie zarządzanie aktywami, aby dać stopę większą od benchmarku (za: Dankowski 2008). 
Podmiotem, który tworzy ETF, jest spółka inwestycyjna określana mianem sponsora funduszu. Określa on zasadniczy cel inwestycyjny funduszu przez wskazanie składu i proporcji instrumentów finansowych, które będą tworzyły fundusz. Sponsor poszukuje również inwestorów instytucjonalnych (m.in. banki, domy maklerskie, spółki inwestycyjne), którzy mają instrumenty finansowe z koszyka indeksu i byliby zainteresowani ich zdeponowaniem, a następnie nabyciem w zamian jednostek ETF. Emisja i przekazanie jednostek ETF odbywa się po podpisaniu z inwestorami umów partycypacyjnych. Posiadacze jednostek ETF mogą je utrzymywać w swoim portfelu lub przekazać w części albo w całości na rynek giełdowy, gdzie zostaną one sprzedane inwestorom indywidualnym ${ }^{2}$.

Pierwsze próby utworzenia funduszu typu ETF podjęto w roku 1989, kiedy na rynku amerykańskim uruchomiono instrument Index Participation Shares. Niestety na skutek protestu Chicago Mercantile Exchange oraz małego zainteresowania inwestorów wycofano produkt z rynku. W 1990 r. rozpoczęły się notowania Toronto 35 Index Participation Units (TIP) ${ }^{3}$, który uważany jest za prekursora współczesnych funduszy ETF. Pierwszy sensu stricte ETF rozpoczął działalność w styczniu 1993 r. - Standard \& Poor's (Standard \& Poor's Depositary Receipts, znany jako SPDR lub „Spiders”) - i jest dziś jednym z największych i najbardziej aktywnie funkcjonujących funduszy ${ }^{4}$.

W marcu 1996 r. na Wall Street zadebiutował pierwszy międzynarodowy EFS (Europejski Fundusz Społeczny), pierwszy fundusz ETF rynków wschodzących. Z czasem wachlarz dostępnych rodzajów funduszy ETF znacznie się zwiększył. W grudniu 1998 r. powstały w USA pierwsze fundusze ETF ukierunkowane na główne sektory, a w czerwcu 2000 r. - pierwsze fundusze rynku nieruchomości. Z kolei w 2000 r. w Kanadzie uruchomiono pierwszy dłużny fundusz ETF, natomiast w lipcu 2002 r. zadebiutował na rynku amerykańskim pierwszy fundusz obligacji (Bond ETF). Pierwszy fundusz towarowy pojawił się w Kanadzie w marcu 2001 r., natomiast debiut funduszy towarowych na rynku amerykańskim miał miejsce w listopadzie 2004 r., kiedy działalność zainaugurował SPDR Gold Shares (GLD), który

2 Więcej o mechanizmie tworzenia i istocie ETF znaleźć można m.in. w pracy: Gabryelczyk (2009, s. 230 i n.).

3 Po włączeniu do funduszu iUnits S \& P/TSE 60 Index Participation Fund obecnie funkcjonuje pod nazwą iShares S \& P/TSX 60 Index ETF.

4 Więcej o genezie i rozwoju funduszy ETF znaleźć można m.in. w pracy: Miziołek (2013, s. 462 i n.). 
stara się duplikować zmiany cen złota. W lutym 2005 r. zainaugurował działalność pierwszy lewarowany (odwrotny) ETF. Natomiast w roku 2006 pojawił się pierwszy ETF z ekspozycją na kontrakty terminowe, a nieco później na rynek private equity.

Jak wynika z rysunku 1, w latach 2003-2014 nastąpił prawie 13-krotny wzrost wartości aktywów zarządzanych przez fundusze ETF, przy ponad 14-krotnym wzroście ich liczby. Świadczy to przede wszystkim o rosnącym zainteresowaniu ze strony inwestorów tą formą lokowania kapitału. Należy zwrócić uwagę, że globalny kryzys finansowy w 2008 r. tylko na krótko wyhamował rozwój tej grupy instrumentów finansowych, po czym nastąpił wyraźny wzrost.

Rysunek 1. Wartość aktywów netto (w mld \$) oraz liczba funduszy ETF na świecie w latach 2003-2014

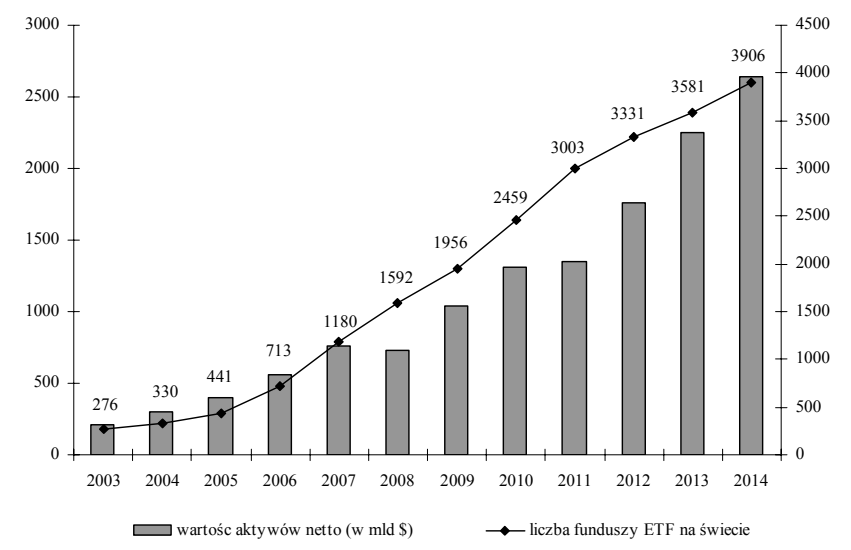

Źródło: opracowanie własne na podstawie informacji The Statistics Portal, www.statista.com (30.06.2015); Lan et al. (2015), www.altii.de (30.06.2015).

Najbardziej rozbudowany jest amerykański rynek funduszy ETF (por. rysunek 2), choć udział rynku amerykańskiego w globalnym rynku funduszy ETF od 2007 r. systematycznie maleje (spadek o 16\%). Na koniec 2014 r. wartość tego rynku kształtowała się na poziomie 1922,46 mld dolarów. Dla porównania - rynek europejski szacuje się na 438,87 mld dolarów, a rynek Azji i Pacyfiku na 201,35 mld dolarów (Lan et al. 2015, s. 100). 
W Europie fundusze ETF zadebiutowały w kwietniu 2000 r. - pierwszymi giełdami, na których notowano ETF-y, były Deutsche Börse i London Stock Exchange, a następnie Stockholm Stock Exchange. W roku 2001 fundusze zadebiutowały w Paryżu, Amsterdamie i Szwajcarii. W Polsce debiut funduszy ETF miał miejsce 22 września 2010 r., kiedy odbyło się pierwsze notowanie Lyxor ETF WIG20. Obecnie (lipiec 2015 r.) na GPW notowane są tytuły uczestnictwa trzech funduszy ETF: Lyxor ETF WIG20, Lyxor ETF S\&P500, Lyxor ETF DAX. Są one zgodne $\mathrm{z}$ wymogami dyrektywy europejskiej dotyczącej funkcjonowania funduszy otwartych (UCITS III). Emitentem wszystkich funduszy jest Lyxor Asset Management należący do grupy kapitałowej Société Górale.

Rysunek 2. Liczba funduszy ETF na świecie oraz w USA w latach 2003-2014

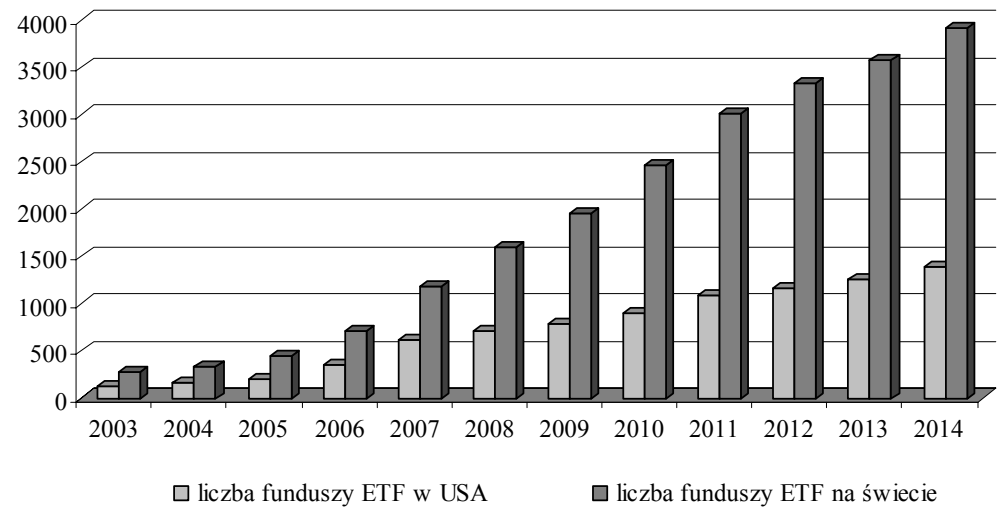

Źródło: opracowanie własne na podstawie informacji The Statistics Portal, www.statista.com (30.06.2015); Lan et al. (2015), www.altii.de (30.06.2015).

Alokacja kapitału w fundusze ETF ma wiele pozytywnych i negatywnych stron. Wśród zalet inwestowania w ETF-y wymienić należy (Gabryelczyk 2009, s. 238 i n.; Miziołek 2013, s. 371 i n.): niskie koszty zarządzania, elastyczność i bieżącą wycenę, przejrzystość i prostotę, możliwość ekspozycji na wybrany region, sektor czy segment rynku, przez co maksymalizujemy dywersyfikację portfela, niskie bariery wejścia, bezpieczeństwo. Fundusze ETF nie są jednakże pozbawione wad - wśród najistotniejszych wymienić należy: brak możliwości selekcji spółek lub walorów 
wchodzących w skład indeksów, ryzyko walutowe, brak możliwości uzyskania ponadprzeciętnej stopy zwrotu, tracking error, a w przypadku polskich inwestorów - znikoma oferta funduszy ETF w Polsce.

\section{Rynek towarowych funduszy ETF}

Początkowo fundusze ETF tworzone były w celu odwzorowywania zachowań tradycyjnych indeksów rynku akcji. W miarę wzrostu popularności tej formy inwestycji zaczęły jednak powstawać produkty coraz bardziej wyspecjalizowane. Inwestowanie w towarowe fundusze ETF oznacza, że można uzyskać ekspozycję na dowolne towary - takie jak złoto, pszenica lub ropa - bez konieczności inwestycji bezpośrednich. Inwestycje za pośrednictwem funduszy charakteryzują się wyższą płynnością i bezpieczeństwem zwłaszcza w odniesieniu do bezpośrednich inwestycji w towary. Zakup jednostek uczestnictwa towarowych funduszy ETF czyni inwestora posiadaczem określonej ilości towaru, a nie ponosi on kosztów jego przechowywania, transportu czy ubezpieczenia.

Tabela 1. Aktywa funduszy ETF w latach 2012-2014

\begin{tabular}{|c|c|c|c|c|c|c|c|}
\hline \multirow{2}{*}{ Rok } & $\begin{array}{c}\text { Aktywa ETF } \\
\text { ogółem } \\
\text { [mld \$] }\end{array}$ & \multicolumn{2}{|c|}{ Equity ETF } & \multicolumn{2}{|c|}{ ETF o stałym dochodzie } & \multicolumn{2}{|c|}{ Towarowe ETF } \\
\cline { 3 - 8 } & {$[$ mld \$] } & $\begin{array}{c}\text { Udział } \\
\text { w aktywach } \\
\text { ogółem } \\
{[\%]}\end{array}$ & {$[$ [mld \$] } & $\begin{array}{c}\text { Udział } \\
\text { w aktywach } \\
\text { ogółem } \\
{[\%]}\end{array}$ & [mld \$] & $\begin{array}{c}\text { Udział } \\
\text { w aktywach } \\
\text { ogółem } \\
{[\%]}\end{array}$ \\
\hline 2012 & 1757,196 & 1355,158 & 77,12 & 354,567 & 20,18 & 40,555 & 2,31 \\
\hline 2013 & 2251,671 & 1851,325 & 82,22 & 367,223 & 16,31 & 23,273 & 1,03 \\
\hline 2014 & 2640,532 & 2153,308 & 81,55 & 449,500 & 17,02 & 20,019 & 0,76 \\
\hline
\end{tabular}

Źródło: opracowanie własne na podstawie Lan et al. (2015), www.altii.de (30.05.2015).

Rynek towarowych funduszy ETF ${ }^{5}$ jest dużo skromniejszy w porównaniu z globalnym rynkiem funduszy ETF. Rozpatrując poziom aktywów towarowych funduszy ETF (tabela 1), można stwierdzić, że o ile jest to trzecia co do wysokości aktywów grupa funduszy, to jednak udział w aktywach ogółem funduszy ETF jest

\footnotetext{
5 W literaturze towarowe fundusze ETF często określane są również mianem funduszy ETC (exchange traded commodities).
} 
znikomy. Dodatkowo wraz ze spadkami na rynku surowców zauważalny jest istotny odpływ kapitału.

Inwestorzy mają do dyspozycji dwa rodzaje towarowych funduszy ETF:

a) commodities-related ETF - to fundusz ETF inwestujący w akcje spółek działających na rynkach towarowych. Oferują one ograniczoną ekspozycję na rynek towarowy i wykazują zazwyczaj silniejszą korelację z indeksami rynku akcji niż z indeksami rynku towarowego;

b) commodities-linked $\mathrm{ETF}^{6}$ - to kategoria funduszy ETF inwestujących bezpośrednio $\mathrm{w}$ instrumenty rynku towarowego. Powstają zarówno fundusze specjalizujące się $\mathrm{w}$ inwestycjach $\mathrm{w}$ jeden rodzaj towaru (np. złoto, ropa naftowa), jak i fundusze inwestujące w zdywersyfikowane portfele aktywów towarowych oparte na indeksach rynku towarowego.

Różnorodność towarowych funduszy ETF sprawia, że w pracy ograniczono się do analizy funduszy ETF opartych na metalach szlachetnych. Jak już wcześniej wspomniano, fundusze oparte na notowaniach metali szlachetnych są najpopularniejszą grupą towarowych funduszy ETF. Rynek surowców w ostatnich latach zanotował wyraźne wzrosty, ale także spektakularne spadki (rysunek 3). Przyczyną tego stanu rzeczy jest oczywiście zmienny popyt na metale szlachetne, słaba koniunktura gospodarcza i zmienny kurs dolara.

Najbardziej popularnym metalem szlachetnym jest oczywiście złoto, ale można inwestować również w srebro ${ }^{7}$, platynę $e^{8}$ czy pallad ${ }^{9}$. Chociaż większość inwestorów

${ }^{6}$ Fundusze te występują również w zbliżonych pod względem prawnym i organizacyjnym formach exchange traded commodities (ETC) i exchange traded notes (ETN).

7 Srebro jest nadal niedocenianą formą inwestycji i lokaty kapitału. Określane jest często mianem ,złota dla ubogich”, a na rynku widoczne jest wyraźne niedowartościowanie tego metalu szlachetnego względem złota, choć srebro ma dużo korzystniejsze własności dla przemysłu. Na niekorzyść inwestycji w srebro przemawia fakt, że zakup srebra jest obciążony podatkiem VAT, który nie występuje przy inwestycjach w złoto.

8 Platyna jest metalem, który występuje w przyrodzie 15 razy rzadziej niż złoto. Produkcja platyny zdominowana jest przez dwa kraje - RPA i Rosję, które dostarczają ponad $90 \%$ światowej produkcji, co ma olbrzymi wpływ na kształtowanie się ceny tego metalu. Platyna początkowo wykorzystywana była przede wszystkim w jubilerstwie, w medycynie (sprzęt medyczny, stomatologia), w przemyśle elektronicznym i chemicznym, ale najszerzej w przemyśle motoryzacyjnym - jako katalizator.

9 Pallad odkrył w 1803 r. W. Wollaston. W przyrodzie pallad występuje bardzo rzadko (w stopach z platyną i złotem, w siarczkach żelaza, niklu i miedzi). Wyglądem przypomina platynę, ale jest lżejszy, twardszy i przede wszystkim tańszy. Wykorzystywany jest głównie w przemyśle motoryzacyjnym (ponad 50\% udziału konsumpcji podaży), elektronicznym, w stomatologii, w medycynie (leczenie 
kojarzy metale szlachetne z biżuterią i numizmatyką, to należy pamiętać, że mają one olbrzymie zastosowanie w przemyśle. W ostatnich latach rośnie zainteresowanie tymi metalami szlachetnymi jako produktami inwestycyjnymi.

Tabela 2. Popyt i podaż metali szlachetnych w latach 2009-2014

\begin{tabular}{|c|c|c|c|c|c|c|}
\hline Rok & 2009 & 2010 & 2011 & 2012 & 2013 & 2014 \\
\hline \multicolumn{7}{|c|}{ Złoto [tony] } \\
\hline Popyt ogółem & 3673,7 & 4213,3 & 4728,1 & 4690,3 & 4436,3 & 4212,4 \\
\hline w tym popyt inwestycyjny & 1476,5 & 1622,9 & 1729,8 & 1606,2 & 786,0 & 820,6 \\
\hline Podaż ogółem & 4024,0 & 4354,8 & 4505,1 & 4463,7 & 4282,2 & 4410,0 \\
\hline w tym wydobycie kopalń & 2575,0 & 2739,4 & 2826,5 & 2869,7 & 3060,3 & 3135,0 \\
\hline \multicolumn{7}{|c|}{ Srebro [mln uncji] } \\
\hline Popyt ogółem & 860,4 & 1030,7 & 1074,8 & 963,2 & 1112,4 & 1066,7 \\
\hline Podaż ogółem & 915,6 & 1073,3 & 1041,1 & 1005,2 & 1000,5 & 1061,8 \\
\hline w tym wydobycie kopalń & 716,3 & 751,2 & 755,3 & 789,3 & 835,3 & 877,5 \\
\hline \multicolumn{7}{|c|}{ Platyna [tys. uncji] } \\
\hline Popyt ogółem & 6750 & 7172 & 7501 & 7458 & 7153 & 7284 \\
\hline w tym popyt inwestycyjny & 313 & 95 & 312 & 282 & 141 & 138 \\
\hline Podaż ogółem & 7330 & 7608 & 8001 & 7239 & 7490 & 6269 \\
\hline w tym wydobycie kopalń & 6049 & 6184 & 6401 & 5803 & 5952 & 4697 \\
\hline \multicolumn{7}{|l|}{ Pallad [tys. uncji] } \\
\hline Popyt ogółem & 7850 & 9735 & 8560 & 9970 & 9630 & 10687 \\
\hline w tym popyt inwestycyjny & 625 & 1095 & -565 & 470 & 75 & 932 \\
\hline Podaż ogółem & 7100 & 7355 & 7360 & 6530 & 6430 & 6104 \\
\hline
\end{tabular}

Źródło: opracowanie własne na podstawie raportów World Gold Council (www.gold.org), The Silver Instytut (www.silverinstitute.org), raportów Platinum \& Palladium (www.gfms.co.uk).

Srebro, mimo że ma ponad 10 tys. zastosowań przemysłowych, nadal zachowuje się głównie jak metal szlachetny i podąża za cenami złota. Ceny srebra rosną szybciej w czasie wzrostów cen złota, ale jednocześnie odnotowuje się głębsze spadki w okresie spadków cen złota. Analizując poziom parytetu złota do srebra (gold/ silver ratio) z ostatnich lat, który porównuje ceny srebra i złota, należy zauważyć, że utrzymuje się on na dosyć wysokim poziomie - oscyluje na poziomie 50-80 (przez wiele lat poziom wskaźnika był niższy niż 20:1; wraz ze wzrostem ceny obu metali zmniejsza się dysproporcja cenowa miedzy nimi - najniższe wartości na poziomie

raka), w przemyśle jubilerskim. Największym producentem palladu jest Rosja (spółka Norilsk Nickel) i RPA. 
30-40 zanotowano w 2011 r.). Tak wysokie wartości wskaźnika wskazują na fakt, że srebro przedstawia dużo większą wartość inwestycyjną niż złoto i ma duże możliwości wzrostu, zatem w najbliższym czasie można się spodziewać wzrostu jego cen, tym bardziej że wzrasta popyt na srebro, a podaż nie ulega drastycznym wzrostom (tabela 2).

Rysunek 3. Ceny metali szlachetnych w okresie 1.01.2009-30.06.2015
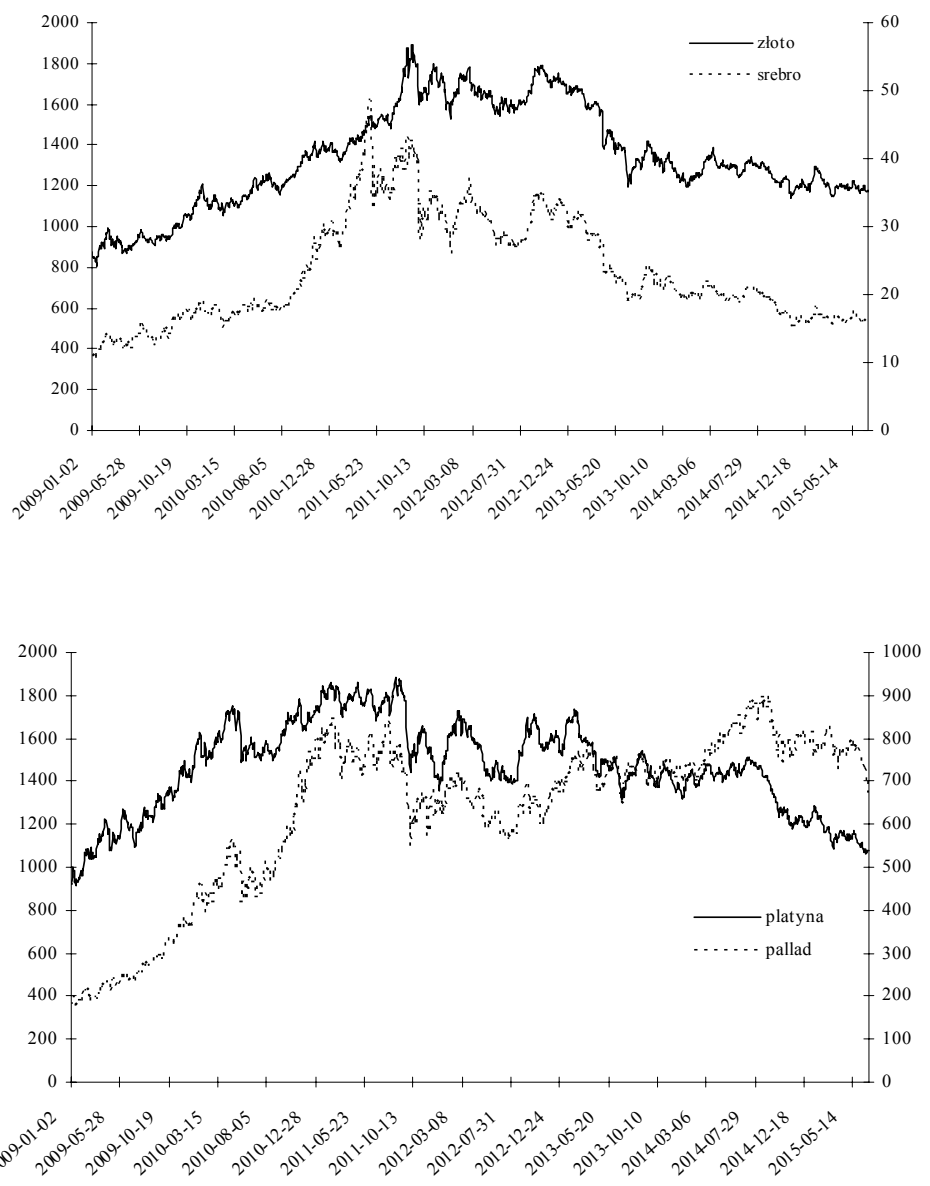

Źródło: opracowanie własne na podstawie www.kitco.com (5.07.2015). 
Rośnie również zainteresowanie platyną i palladem jako produktami inwestycyjnymi. Są one jednak mało popularną inwestycją, ponieważ w zasadzie traktuje się je jako metale przemysłowe. $Z$ drugiej zaś strony dla wielu przeciętnych inwestorów indywidualnych są poza zasięgiem możliwości finansowych. Należy również pamiętać o dużej zmienności cen tych metali spowodowanej małą podażą i ograniczoną liczbą dostawców.

\section{Złote fundusze ETF}

Największą grupą wśród towarowych funduszy ETF są fundusze oparte na złocie. Najpopularniejszymi ETF-ami towarowymi opartymi bezpośrednio lub pośrednio na notowaniach złota są:

- iShares Gold Trust (IAU) - utworzony 21 stycznia 2005 r., fundusz zarządzany przez grupę BlackRock, aktywa: $6280,57 \mathrm{mln} \$^{10}$, nie ma wyodrębnionego benchmarku, jego celem jest jednak odwzorowanie cen złota (1/100 uncji),

- SPDR Gold Shares (GLD) - utworzony 18 listopada 2004 r., fundusz zarządzany przez State Street Global Advisors, aktywa: 26 642,46 mln \$, jego cena odzwierciedla $1 / 10$ ceny uncji złota,

- ETFS Physical Swiss Gold Shares (SGOL) - utworzony 9 września 2009 r., zarządzany przez ETF Securities Limited, aktywa: 886,18 mln \$, aktywa w postaci złota przechowywane są w Szwajcarii ze względu na niższe koszty,

- PowerShares DB Gold Fund (DGL) - utworzony 5 stycznia 2007 r., zarządzany przez DB Commodity Services LLC, aktywa: 137,86 mln \$,

- ProShares Ultra Gold (UGL) - utworzony 1 grudnia 2008 r., zarządzany przez ProShares, aktywa: 87,96 $\mathrm{mln} \$$,

- ProShares Ultra Short Gold (GLL) - utworzony 1 grudnia 2008 r., zarządzany przez ProShares, aktywa: 74,68 $\mathrm{mln} \$$,

- DB Gold Double Long - utworzony 27 lutego 2008 r., zarządzany przez DB Commodity Services LLC, aktywa: 119,57 $\mathrm{mln} \$$.

10 Stan aktywów netto poszczególnych funduszy z dnia 30.06.2015 na podstawie www.bloomberg.com. 
W tabeli 3 przedstawiono stopy zwrotu dla prezentowanych funduszy opartych na złocie. Można zauważyć, że w większości przypadków lata 2009-2012 były okresem wyraźnych wzrostów poszczególnych funduszy (zwłaszcza rok 2010), podczas gdy załamanie rynku nastąpiło w $2013 \mathrm{r}$. W badanym okresie najwięcej zyskały fundusze, które najdłużej funkcjonują na rynku funduszy ETF. Dla porównania złoto w analogicznym okresie zyskało prawie $34 \%$.

Wyjątkiem był fundusz GLL, którego wyniki znacznie odbiegają od wyników pozostałych funduszy. Należy jednak pamiętać, że fundusz ultra short zapewnia dwukrotny lewar zarówno w przypadku zysków, jak i strat - jeżeli cena instrumentu odwzorowywanego wzrasta o $10 \%$, to fundusz traci $20 \%$ na wartości i odwrotnie.

Tabela 3. Stopy zwrotu [\%] wybranych złotych funduszy ETF w latach 2009 - I półrocze 2015

\begin{tabular}{|c|r|r|r|r|r|r|r|}
\cline { 2 - 7 } \multicolumn{1}{c|}{} & IAU & GLD & \multicolumn{1}{c|}{ SGOL } & DGL & UGL & GLL & DGP \\
\hline 2009 & 24,45 & 24,45 & $10,54^{3}$ & 22,99 & 42,29 & $-46,29$ & 46,48 \\
\hline 2010 & 29,42 & 29,27 & 29,23 & 27,89 & 58,28 & $-46,28$ & 62,37 \\
\hline 2011 & 9,57 & 9,57 & 9,58 & 8,55 & 11,72 & $-28,74$ & 10,90 \\
\hline 2012 & 6,89 & 6,60 & 6,61 & 5,33 & 8,01 & $-21,00$ & 9,28 \\
\hline 2013 & $-28,26$ & $-28,33$ & $-28,34$ & $-29,63$ & $-51,65$ & 65,38 & $-51,76$ \\
\hline 2014 & $-2,05$ & $-2,19$ & $-2,12$ & $-3,02$ & $-6,91$ & $-3,20$ & $-6,37$ \\
\hline $2015^{1}$ & $-0,87$ & $-1,07$ & $-1,09$ & $-1,38$ & $-3,57$ & $-1,40$ & $-3,45$ \\
\hline $2009-$ & 31,40 & 30,31 & $15,77^{4}$ & 21,04 & 17,96 & $-74,36$ & 25,71 \\
\hline $2015^{2}$ & & & & & &
\end{tabular}

${ }^{1}$ Stopy zwrotu liczone w okresie 1.01.2015-30.06.2015; ${ }^{2}$ stopy zwrotu liczone w okresie 1.01.2009-30.06.2015; ${ }^{3}$ stopy zwrotu liczone w okresie 9.09.2009-31.12.2009; ${ }^{4}$ stopy zwrotu liczone w okresie 9.09.2009-30.06.2015.

Źródło: obliczenia własne.

Fundusze ETF realizują pasywne strategie inwestycyjne i z założenia powinny wiernie naśladować zachowania referencyjnego indeksu lub koszyka aktywów. Fundusz śledzi zachowanie indeksu, nabywając kontrakty futures, na których podstawie wyznaczana jest wartość indeksu, oraz kontrakty futures lub opcje na sam indeks albo pozagiełdowe swapy indeksowe (por. Irwin, Sanders 2011). W wielu przypadkach punktem odniesienia są indeksy rynku towarowego, które są konstruowane na podstawie szerokiego przekroju cen towarów różnych klas lub na podstawie cen określonej klasy towarów. Pierwszym indeksem towarowym był CRB Futures Price Index, skonstruowany przez amerykańską firmę Commodity Research Bureau Inc. 
i opublikowany po raz pierwszy w roku 1957. W chwili obecnej największą popularnością cieszą się cztery szerokie indeksy rynku towarowego:

- S \& P GSCI Commodity Index - powstał w 1991 r., zawiera 24 komponenty, W ogromnej mierze jest jednak zdominowany przez ceny surowców energetycznych, metale stanowią ok. 11\% składu, wagi oparte są wyłącznie na wielkości produkcji, zatem mogą niedoszacowywać wartości inwestycyjnej określonych towarów,

- DJ-UBS Commodity Index - powstał w 1998 r., zawiera 23 komponenty, w konstrukcji wag uwzględniono wielkości produkcji poszczególnych towarów, ale również wielkości obrotów danym towarem na rynkach giełdowych; jest to indeks, na którego wartość znaczący wpływ mają metale i surowce energetyczne (po ok. 33\%),

- Rogers International Commodity Index (RICI) - powstał w 1996 r., zawiera 38 komponentów, kalkulacja indeksu opiera się na wagach wyznaczonych na podstawie płynności instrumentów bazowych i wielkości produkcji, metale stanowią ponad $20 \%$ składu indeksu,

- The Thomson Reuters/Jefferies CRB Index - powstał w 1957 r., zawiera 19 komponentów, konstrukcja indeksu dokonywana jest przez ustalenie stałych wag udziałów poszczególnych towarów, które podzielono na cztery klasy istotności - metale mają wagę ok. $20 \%$.

W tabeli 4 przedstawiono ocenę zależności między stopami zwrotu złotych funduszy ETF, stopami zwrotu wybranych indeksów towarowych oraz stopami zwrotu złota i podstawowych indeksów giełdy amerykańskiej (S \& P 500 oraz Dow Jones).

Tabela 4. Korelacja stóp zwrotu złotych funduszy ETF z wybranymi indeksami towarowymi, giełdowymi i złotem w latach 2009 - I półrocze 2015

\begin{tabular}{|l|c|c|c|c|c|c|c|}
\cline { 2 - 7 } \multicolumn{1}{c|}{} & IAU & GLD & SGOL $^{1}$ & DGL & UGL & GLL & DGP \\
\hline CRB & 0,3442 & 0,3435 & 0,4024 & 0,3418 & 0,3457 & $-0,3443$ & 0,3450 \\
\hline GSCI & 0,2763 & 0,2734 & 0,3360 & 0,2724 & 0,2753 & $-0,2752$ & 0,2768 \\
\hline RICI & 0,3478 & 0,3467 & 0,4087 & 0,3448 & 0,3483 & $-0,3486$ & 0,3492 \\
\hline DJ-UBS & 0,4286 & 0,4276 & 0,4899 & 0,4258 & 0,4302 & $-0,4288$ & 0,4289 \\
\hline Złoto & 0,5824 & 0,5834 & 0,5915 & 0,5847 & 0,5856 & $-0,5773$ & 0,5874 \\
\hline S\&P500 & 0,0587 & 0,0587 & 0,0901 & 0,0534 & 0,0595 & $-0,0575$ & 0,0637 \\
\hline DJ & 0,0462 & 0,0459 & 0,0802 & 0,0397 & 0,0470 & $-0,0447$ & 0,0504 \\
\hline
\end{tabular}

${ }^{1}$ Współczynniki korelacji liczone w okresie 9.09.2009-30.06.2015.

Źródło: obliczenia własne. 
Jak wynika z tabeli 4, stopy zwrotu złotych funduszy ETF najsilniej skorelowane są ze stopami zwrotu złota. Wartości współczynnika korelacji oscylują wokół 0,58. Najwyższe wartości korelacji zanotowano w ostatnich latach - począwszy od 2013 r. wartość współczynnika korelacji liniowej Pearsona wynosiła ponad 0,65. Najniższe wartości zanotowano w roku 2010 i 2012, kiedy wartość współczynnika korelacji oscylowała na poziomie 0,5 .

Większość funduszy ETF opartych na metalach szlachetnych może stanowić alternatywę inwestowania na wybranych giełdach - niską korelację otrzymano dla indeksów giełdy amerykańskiej. Można zatem postawić hipotezę, że złote ETF-y stanowią doskonały dywersyfikator portfela inwestycyjnego, pozwalają bowiem na obniżenie ryzyka przy zachowaniu możliwości wzrostu portfela.

Zwraca uwagę dość niska korelacja z indeksami towarowymi. Najwyższą korelację poszczególne złote fundusze ETF uzyskały z DJ-UBS Commodity Index, co jak już wcześniej podkreślono, wynika z faktu, że indeks ten w swoim składzie ma najwyższy udział metali. W badanym okresie współczynnik korelacji w ujęciu rocznym był zróżnicowany. Najsłabiej fundusze skorelowane były z DJ-UBS Commodity Index w 2009 r. (współczynnik 0,3), a najsilniej w 2013 r. - współczynnik na poziomie 0,6 . Z kolei najsłabiej fundusze ETF skorelowane były $\mathrm{z}$ indeksem S\&P GSCI (na poziomie 0,27). Wynika to przede wszystkim z faktu, że ten indeks w swoim składzie zawiera najmniejszy udział metali. Wartość współczynnika korelacji również była zmienna - najniższa w 2009 r. (0,1), a najwyższa w 2010 i 2012 r. $(0,38)$.

Różnica między stopą zwrotu funduszu ETF a stopą zwrotu replikowanego indeksu (aktywa) określana jest jako błąd naśladowania (tracking error). Parametr ten jest jednym z mierników oceny efektywności pasywnie zarządzanych funduszy. W literaturze występuje wiele miar, które opisują błąd naśladowania. W niniejszej pracy wykorzystano wybrane mierniki $T E_{i}$ opisane wzorami (1)-(3).

$$
T E_{1}=\sqrt{\frac{1}{N-1} \sum\left(r_{F}-r_{B}\right)^{2}} \text { (za: Vardharaj et al. 2004, s. 37-47) }
$$




$$
\begin{gathered}
T E_{2}=\sqrt{\frac{1}{N-1} \sum\left(R D_{t}-\overline{R D}\right)^{2}} \quad R D_{t}=\left|r_{F}-r_{B}\right| \\
T E_{3}=\sigma_{F} \sqrt{\left(1-\rho_{F B}\right)^{2}} \text { (za: Miziołek 2013, s. 509) }
\end{gathered}
$$

gdzie:

$r_{F}-$ dzienna logarytmiczna stopa zwrotu funduszu ETF,

$r_{B}$ - dzienna logarytmiczna stopa zwrotu wzorca odwzorowania (benchmarku),

$N$ - liczba okresów zwrotu,

$\rho_{F B}-$ współczynnik korelacji między stopami zwrotu funduszu i benchmarku,

$\sigma_{F}-$ odchylenie standardowe stóp zwrotu funduszu ETF.

Im niższa jest wartość błędu naśladowania, tym lepsze jest odzwierciedlenie wyników indeksu lub grupy aktywów, a zatem ryzyko jest niższe. Z kolei im wartość tracking error jest wyższa, tym fundusz ETF gorzej odwzorowuje rezultaty osiągane przez indeks lub aktywa, a więc ryzyko jest wyższe. Dodatkowo w sytuacji, w której zmienność stóp zwrotu wzrasta, rośnie również wartość wskaźnika błędu odwzorowania $\left(T E_{3}\right)$. W literaturze postuluje się, aby w przypadku funduszy zarządzanych pasywnie błąd odwzorowania nie przekroczył 1-1,5\%. W przypadku jednak zajścia nieoczekiwanych zdarzeń na rynkach finansowych istnieje ryzyko zwiększenia się tego odchylenia.

Wartości wskaźników $T E_{1}-T E_{2}$ są dość zróżnicowane. Najniższe wartości uzyskano dla funduszy ETF, które oparte są bezpośrednio na złocie. Błędy replikacji nie przekraczają $1,5 \%$, a ich niskie wartości są zgodne z pasywnym charakterem funduszy. Przyczyna zwiększenia błędu replikacji tkwi przede wszystkim w podwyższonej zmienności dziennych stóp zwrotu, jak również istotnej różnicy między zmiennością stóp zwrotu funduszy i indeksów towarowych.

Najniższe wartości wskaźnika $T E_{3}$ otrzymano dla instrumentów, dla których zróżnicowanie stóp zwrotu $\mathrm{w}$ analizowanym okresie jest na zbliżonym poziomie do zróżnicowania stóp zwrotu indeksów towarowych i złota. Największe wartości błędu naśladowania zanotowano w okresach o wyższym odchyleniu standardowym dziennych stóp zwrotu. Należy również zauważyć, że odchylenia od notowań indek- 
su bazowego działają zazwyczaj na korzyść inwestorów, pozwalają bowiem osiągać wyższe stopy zwrotu.

Tabela 5. Wartości wybranych błędów odwzorowania [\%] złotych funduszy ETF od 1.01.2009 do 31.06.2015

\begin{tabular}{|c|c|c|c|c|c|c|c|}
\hline & IAU & GLD & $\mathrm{SGOL}^{1}$ & DGL & UGL & GLL & DGP \\
\hline & \multicolumn{7}{|c|}{$T E_{1}$} \\
\hline CRB & 1,194 & 1,268 & 1,270 & 1,283 & 2,178 & 2,827 & 2,201 \\
\hline GSCI & 1,468 & 1,544 & 1,548 & 1,558 & 2,342 & 2,982 & 2,361 \\
\hline RICI & 1,254 & 1,332 & 1,335 & 1,346 & 2,193 & 2,911 & 2,213 \\
\hline DJ-UBS & 1,111 & 1,192 & 1,195 & 1,206 & 2,081 & 2,910 & 2,105 \\
\hline \multirow[t]{2}{*}{ Złoto } & 1,027 & 1,051 & 1,051 & 1,057 & 1,878 & 3,091 & 1,897 \\
\hline & \multicolumn{7}{|c|}{$T E_{2}$} \\
\hline CRB & 0,878 & 0,880 & 0,770 & 0,889 & 1,539 & 1,934 & 1,563 \\
\hline GSCI & 1,076 & 1,080 & 0,911 & 1,086 & 1,658 & 2,030 & 1,677 \\
\hline RICI & 0,932 & 0,935 & 0,798 & 0,942 & 1,557 & 1,987 & 1,576 \\
\hline DJ-UBS & 0,820 & 0,823 & 0,715 & 0,830 & 1,475 & 1,980 & 1,497 \\
\hline \multirow[t]{2}{*}{ Złoto } & 0,749 & 0,748 & 0,718 & 0,754 & 1,314 & 2,132 & 1,334 \\
\hline & \multicolumn{7}{|c|}{$T E_{3}$} \\
\hline CRB & 0,753 & 0,755 & 0,669 & 0,768 & 1,507 & 3,062 & 1,525 \\
\hline GSCI & 0,831 & 0,836 & 0,743 & 0,849 & 1,669 & 2,905 & 1,684 \\
\hline RICI & 0,748 & 0,751 & 0,662 & 0,765 & 1,501 & 3,072 & 1,515 \\
\hline DJ-UBS & 0,656 & 0,658 & 0,571 & 0,670 & 1,313 & 3,255 & 1,330 \\
\hline Złoto & 0,479 & 0,479 & 0,457 & 0,485 & 0,955 & 3,593 & 0,961 \\
\hline
\end{tabular}

${ }^{1}$ Współczynniki liczone w okresie 9.09.2009-30.06.2015.

Źródło: obliczenia własne.

\section{Fundusze ETF oparte na srebrze, platynie i palladzie}

Srebro, platyna i pallad także należą do grupy metali szlachetnych i budzą coraz większe zainteresowanie wśród inwestorów. Grupa tych funduszy nie jest aż tak liczna, jak funduszy opartych na złocie, ale równie interesująca. Najbardziej popularne srebrne ETF-y to: 
- iShares Silver Trust Fund (SLV) - utworzony 28 kwietnia 2006 r., fundusz zarządzany przez grupę BlackRock, aktywa: 5075,97 $\mathrm{mln} \$^{11}$,

- ProShares Ultra Silver Fund (AGQ) - utworzony 1 grudnia 2008 r., fundusz zarządzany przez ProShares, aktywa: 282,56 $\mathrm{mln} \$$,

- DB Power Shares Silver Fund (DBS) - utworzony 5 stycznia 2007 r., fundusz zarządzany przez DB Commodity Services LLC, aktywa: 20,18 mln \$,

- ProShares Ultra Short Silver Fund (ZSL) - utworzony 1 grudnia 2008 r., fundusz zarządzany przez ProShares, aktywa: $61,81 \mathrm{mln} \$$,

- ETFS Physical Silver Trust (SIVR) - utworzony 24 lipca 2009 r., fundusz zarządzany przez ETF Securities Limited, aktywa: $285,20 \mathrm{mln} \$$.

W przypadku platynowych funduszy można wymienić ETFS Physical Platinum Shares (PPLT), w przypadku palladu - ETFS Physical Palladium Shares (PALL). Oba utworzono 8 stycznia 2010 r. i zarządza nimi ETF Securities Limited. Aktywa funduszy wynoszą odpowiednio: $554,91 \mathrm{mln} \$$ oraz $306,94 \mathrm{mln} \$$. Niestety w wielu przypadkach zakup udziałów skierowany jest głównie do inwestorów instytucjonalnych, ponieważ wiąże się z zakupem dużej ilości metalu.

Tabela 6. Stopy zwrotu [\%] wybranych funduszy ETF w latach 2009 - I półrocze 2015

\begin{tabular}{|c|c|c|c|c|c|c|c|}
\hline & SLV & AGQ & DBS & ZSL & SIVR & PALL & PPLT \\
\hline 2009 & 44,96 & 71,35 & 45,93 & $-71,91$ & $21,19^{3}$ & \multicolumn{2}{|c|}{-} \\
\hline 2010 & 82,47 & 182,46 & 81,16 & $-79,50$ & 82,16 & $84,99^{4}$ & $10,76^{4}$ \\
\hline 2011 & $-10,74$ & $-47,48$ & $-11,96$ & $-59,60$ & $-10,45$ & $-19,16$ & $-21,74$ \\
\hline 2012 & 9,02 & 5,88 & 9,09 & $-36,90$ & 9,19 & 7,22 & 9,82 \\
\hline 2013 & $-36,30$ & $-64,26$ & $-38,32$ & 80,13 & $-36,11$ & 0,58 & $-11,54$ \\
\hline 2014 & $-19,51$ & $-39,64$ & $-21,74$ & 32,38 & $-19,64$ & 11,30 & $-12,58$ \\
\hline $2015^{1}$ & $-0,20$ & $-3,73$ & $-0,87$ & $-9,09$ & 0,13 & $-15,92$ & $-10,98$ \\
\hline $\begin{array}{l}2009- \\
2015^{2}\end{array}$ & 31,73 & $-44,11$ & 21,48 & $-96,82$ & $10,99^{5}$ & $50,91^{6}$ & $-34,47^{6}$ \\
\hline
\end{tabular}

${ }^{1}$ Stopy zwrotu liczone w okresie 1.01.2015-30.06.2015; ${ }^{2}$ stopy zwrotu liczone w okresie 1.01.2009-30.06.2015; ${ }^{3}$ stopy zwrotu liczone w okresie 24.07.2009-31.12.2009; ${ }^{4}$ stopy zwrotu liczone w okresie 8.01.2010-31.12.2010; ${ }^{5}$ stopy zwrotu liczone w okresie 24.07.2009-30.06.2015; ${ }^{6}$ stopy zwrotu liczone w okresie 8.01.2010-30.06.2015.

Źródło: obliczenia własne. 11 Stan aktywów netto poszczególnych funduszy z dnia 30.06.2015 na podstawie www.bloom-
berg.com. 11 Stan aktywów netto poszczególnych funduszy z dnia 30.06.2015 na podstawie www.bloom-
berg.com. 
W przypadku srebrnych funduszy najbardziej korzystny był rok 2010, kiedy to większość funduszy zanotowała spektakularne wzrosty. Rok 2013 zapoczątkował dość istotny trend spadkowy, który był kontynuowany w latach 2014-2015. Niemniej w badanym okresie (2009-2015) najwyższą stopę zwrotu uzyskał największy srebrny ETF - SLV. Podobnie jak w przypadku złota, najgorsze wyniki zanotował fundusz ultra short - ProShares Ultra Short Silver Fund.

Podobnie jak w przypadku złotych funduszy ETF, również pozostałe analizowane fundusze są dość słabo skorelowane z podstawowymi indeksami giełdy amerykańskiej. W przypadku srebrnych ETF-ów dość słaba jest również korelacja ze stopami zwrotu srebra. W przypadku palladu i platyny korelacja z instrumentem bazowym jest na poziomie ok. 0,6.

Tabela 7. Korelacja stóp zwrotu wybranych funduszy ETF z indeksami towarowymi, giełdowymi i srebrem, platyną oraz palladem w latach 2009 - I półrocze 2015

\begin{tabular}{|l|c|c|c|c|c|c|c|}
\cline { 2 - 8 } \multicolumn{1}{c|}{} & SLV & AGQ & DBS & ZSL & SIVR $^{2}$ & PALL $^{3}$ & PPLT $^{3}$ \\
\hline CRB & 0,486 & 0,486 & 0,482 & $-0,484$ & 0,532 & 0,532 & 0,518 \\
\hline GSCI & 0,419 & 0,420 & 0,412 & $-0,418$ & 0,468 & 0,498 & 0,470 \\
\hline RICI & 0,490 & 0,490 & 0,485 & $-0,487$ & 0,548 & 0,555 & 0,537 \\
\hline DJ-UBS & 0,560 & 0,560 & 0,556 & $-0,557$ & 0,604 & 0,561 & 0,576 \\
\hline Instrument bazowy & 0,374 & 0,382 & 0,375 & $-0,362$ & 0,377 & 0,580 & 0,590 \\
\hline S\&P500 & 0,222 & 0,223 & 0,215 & $-0,220$ & 0,257 & 0,448 & 0,326 \\
\hline DJ & 0,207 & 0,208 & 0,200 & $-0,207$ & 0,242 & 0,435 & 0,312 \\
\hline
\end{tabular}

${ }^{1}$ Odpowiednio srebro, platyna lub pallad; ${ }^{2}$ współczynniki korelacji liczone w okresie 24.07.2009-30.06.2015; ${ }^{3}$ współczynniki korelacji liczone w okresie 8.01.2010-30.06.2015.

Źródło: obliczenia własne.

Najwyższe wartości współczynnika korelacji liniowej Pearsona uzyskano dla stóp zwrotu DJ-UBS Commodity Index, który zawiera największy udział metali spośród analizowanych indeksów towarowych. Najniższe wartości, podobnie jak w przypadku złotych ETF-ów, uzyskano dla S \& P GSCI, który w swojej formule zawiera najmniejszy udział metali. 
Tabela 8. Wartości wybranych błędów odwzorowania [\%] wybranych funduszy ETF od 1.01.2009 do 31.06.2015

\begin{tabular}{|c|c|c|c|c|c|c|c|}
\hline & SLV & AGQ & DBS & ZSL & SIVR $^{2}$ & PALL $^{3}$ & PPLT $^{3}$ \\
\hline & \multicolumn{7}{|c|}{$T E_{1}$} \\
\hline CRB & 1,800 & 3,749 & 1,852 & 4,728 & 1,735 & 1,522 & 1,112 \\
\hline GSCI & 1,944 & 3,781 & 1,997 & 4,873 & 1,863 & 1,634 & 1,344 \\
\hline RICI & 1,803 & 3,715 & 1,855 & 4,810 & 1,715 & 1,503 & 1,142 \\
\hline DJ-UBS & 1,707 & 3,655 & 1,759 & 4,807 & 1,641 & 1,485 & 1,050 \\
\hline \multirow[t]{2}{*}{$\begin{array}{l}\text { Instrument } \\
\text { bazowy }^{1}\end{array}$} & 2,465 & 3,906 & 2,490 & 5,418 & 2,455 & 1,691 & 1,112 \\
\hline & \multicolumn{7}{|c|}{$T E_{2}$} \\
\hline CRB & 1,249 & 2,671 & 1,285 & 3,321 & 1,210 & 0,980 & 0,689 \\
\hline GSCI & 1,339 & 2,673 & 1,374 & 3,404 & 1,257 & 1,010 & 0,788 \\
\hline RICI & 1,255 & 2,647 & 1,289 & 3,367 & 1,193 & 0,959 & 0,689 \\
\hline DJ-UBS & 1,184 & 2,609 & 1,220 & 3,373 & 1,147 & 0,963 & 0,638 \\
\hline \multirow[t]{2}{*}{$\begin{array}{l}\text { Instrument } \\
\text { bazowy }^{1}\end{array}$} & 1,701 & 2,675 & 1,716 & 3,861 & 1,695 & 1,098 & 0,689 \\
\hline & \multicolumn{7}{|c|}{$T E_{3}$} \\
\hline CRB & 1,058 & 2,132 & 1,095 & 6,115 & 0,959 & 0,839 & 0,573 \\
\hline GSCI & 1,196 & 2,406 & 1,243 & 5,843 & 1,090 & 0,900 & 0,630 \\
\hline RICI & 1,050 & 2,116 & 1,089 & 6,127 & 0,926 & 0,798 & 0,551 \\
\hline DJ-UBS & 0,906 & 1,825 & 0,938 & 6,416 & 0,812 & 0,787 & 0,504 \\
\hline $\begin{array}{l}\text { Instrument } \\
\text { bazowy }\end{array}$ & 1,289 & 2,564 & 1,321 & 5,612 & 1,277 & 0,753 & 0,488 \\
\hline
\end{tabular}

${ }^{1}$ Odpowiednio srebro, platyna lub pallad; ${ }^{2}$ współczynniki liczone w okresie 24.07.2009-30.06.2015; ${ }^{3}$ współczynniki liczone w okresie 8.01.2010-30.06.2015.

Źródło: obliczenia własne.

Wartości wskaźników $T E_{1}-T E_{2}$ są dużo bardziej zróżnicowane niż w przypadku złotych funduszy ETF. Najniższe wartości uzyskano dla funduszy ETF, które oparte są bezpośrednio na srebrze. Niskie wartości błędów replikacji otrzymano dla funduszy opartych na palladzie i platynie, co potwierdza pasywny charakter tych funduszy. W wielu przypadkach błędy replikacji znacznie przekraczały literaturowe $1,5 \%$ - najwyższe błędy uzyskano dla funduszy, których stopy zwrotu charakteryzowały się wyższą zmiennością (AGQ i ZSL). 


\section{Podsumowanie}

Rynek towarowych funduszy ETF, choć funkcjonuje jeszcze stosunkowo krótko, stał się już istotną częścią rynku zarządzania aktywami. Ufinansowienie rynków towarowych daje inwestorom możliwość korzystania z instrumentów finansowych bez konieczności inwestycji bezpośrednich. Dodatkową zaletą są niższe koszty wynikające z pasywnego podejścia inwestycyjnego, mającego na celu replikowanie stóp zwrotu instrumentu bazowego.

Umacniający się dolar i gorszy od oczekiwań wzrost gospodarczy ograniczył w ostatnim czasie zapotrzebowanie na surowce, zwłaszcza rynków wschodzących. Znalazło to swoje odzwierciedlenie w spadkach cen towarów. Można zauważyć, że kształtowanie się cen towarów nie jest już uzależnione jedynie od czynników popytowo-podażowych, ale również czynników finansowych (np. strategii inwestycyjnych funduszy).

Ze względu na niskie skorelowanie $\mathrm{z}$ indeksami giełdowymi inwestycje na rynku towarowym należy traktować jako alternatywę pozwalającą na dywersyfikację portfela. Należy mieć przy tym nadzieję, że większość rynków surowcowych w dużej mierze wyczerpała już możliwości spadków, zatem segment rynku towarowego będzie w kolejnych latach jednym z motorów rozwoju rynku asset management na świecie.

\section{Literatura}

Dankowski K. (14.08.2008), Fundusze ETF na trudne czasy, biznes.interia.pl.

Gabryelczyk K. (red.) (2009), Private asset \& Wealth management. Nowe instrumenty i ustugi finansowe, C.H. Beck, Warszawa.

Irwin S.H., Sanders D.R. (2011), Index Funds, Financializtion and Commodity Futures Markets, Applied Economic Perspectives and Policy, Oxford University Press.

Lan S., Mercado S., Rajenda A., Gademsetty A. (2015), ETF Annual Review \& Outlook, Deutsche Bank Securities Inc., www.altii.de.

Miziołek T. (2013), Pasywne zarzadzanie portfelem inwestycyjnym - indeksowe fundusze inwestycyjne i fundusze ETF. Ocena efektywności zarzadzania na przykładzie akcyjnych funduszy ETF rynków wschodzacych, Wydawnictwo Uniwersytetu Łódzkiego, Łódź.

Vardharaj R., Fabozzi F.J., Jones F.J. (2004), Determinants of tracking terror for equity portfolios, „Journal of Investing” vol. 13, nr 2. 
Dostęp elektroniczny: www.stooq.com, www.statista.com, www.gold.org, www.silverinstitute.org, www.kitco.com, www.gfms.co.uk, www.bloomberg.com.

\title{
EFFICIENCY OF THE COMMODITY FUNDS ON THE EXAMPLE OF PRECIOUS METALS
}

\begin{abstract}
The purpose of this article is to characterize commodity ETFs and assessment of their efficiency. Commodity ETF is a new financial instrument on capital market. The basic advantages of ETF are: high liquidity, simplicity and clarity of the instrument, low cost. Commodity ETFs are the most popular means of adding commodity exposure into traditional portfolios of investors. This article is limited only to the analysis of the largest group of commodity ETFs - precious metals funds. The research in the capital market was carried in the period 2009 - I half of 2015.
\end{abstract}

Translated by Urszula Gierałtowska

Keywords: commodity ETFs, precious metals, tracking error, passive management funds JEL Codes: G10, G11, G23 
